\title{
Fiscal Decentralization, Corruption, and Income Inequality: Evidence from Vietnam
}

\author{
Hung Thanh NGUYEN ${ }^{1}$, Thuy Hoang Ngoc VO², Duc Doan Minh LE ${ }^{3}$, Vu Thanh NGUYEN ${ }^{4}$ \\ Received: August 01, 2020 Revised: September 20, 2020 Accepted: October 05, 2020
}

\begin{abstract}
The objective of this research paper is to study the simultaneous relationship between fiscal decentralization, corruption, and income inequality among Vietnamese provinces. We use a balanced panel data set of 63 provinces/cities in Vietnam in the period from 2011 to 2018. The study used 3SLS-GMM (Three Stage Least Squares - Generalized Method of Moments estimator) and GMM-HAC (Generalized Method of Moments - Heteroskedastic and Autocorrelation Consistent estimator). Empirical evidence shows a strong simultaneous relationship: increased corruption will increase regional income disparities, income inequality, and increase fiscal decentralization. In addition, the results also suggest that an increase in per-capita income will reduce the level of corruption, or better control corruption of each province. The degree of increase in income inequality, which reduces fiscal decentralization, is the same for trade liberalization. All demonstrate that there is a simultaneous relationship between fiscal decentralization, corruption, and income inequality. In a region of high public governance quality, fiscal decentralization positively effects its economic growth. This issue will indirectly increase income inequality between provinces within a country. Our findings imply that a country's fiscal decentralization strategy should be linked to improving corruption control and local governance effectiveness, indirectly improving income inequality between localities or regions.
\end{abstract}

Keywords: Decentralization, Corruption, Income Inequality, Economic Growth, Poverty

JEL Classification Code: C33, D73, H71, H73

\section{Introduction}

The relationship between economic growth and income inequality has long been a topic of interest to many researchers in developed and developing countries. Many classical theories suggest that unequal economic growth across regions will lead to income inequality, and this effect can take place in different directions (Kuznets, 1955; Alesina \& Rodrik, 1994; Presson \& Tabellini, 1994; Galor \& Zeira,

${ }^{1}$ First Author. School of Public Finance, University of Economics Ho Chi Minh City, Ho Chi Minh City, Vietnam

${ }^{2}$ Thu Dau Mot University, Thu Dau Mot City, Binh Duong Province, Vietnam

${ }^{3}$ Corresponding Author. School of Accounting, University of Economics Ho Chi Minh City, Ho Chi Minh City, Vietnam [Postal Address: 59C Nguyen Dinh Chieu Street, District 3, Ho Chi Minh City, Vietnam] Email: ledoanminhduc@gmail.com

${ }^{4}$ Nguyen Tat Thanh University, Ho Chi Minh City, Vietnam

(c) Copyright: The Author(s)

This is an Open Access article distributed under the terms of the Creative Commons Attribution Non-Commercial License (https://creativecommons.org/licenses/by-nc/4.0/) which permits unrestricted non-commercial use, distribution, and reproduction in any medium, provided the original work is properly cited.
1993; Aghion \& Bolton, 1997; Benabou, 1996; Perotti, 1996; Knell, 1998). One of the factors that can promote unequal economic growth across regions is that each country's fiscal decentralization has a direct effect on economic growth (Martinez-Vazquez, 2003). Fiscal level is the process of transferring the authority of the scope of spending/revenue from the central to the locality. The degree of decentralization depends on the ability of the local level to make decisions on revenue and expenditure independently within the geography, for local people, without the intervention of the central government (Martinez-Vazquez \& McNab, 1997). Therefore, fiscal decentralization has always been a trend of the world over the past three decades (Lessman, 2011). Reducing income inequality and reducing poverty, is always an essential goal of the policies of most countries, and a particular concern of interest in developing economies. However, the effects of fiscal decentralization on poverty and income inequality have not received much attention in economic theory. Much of the research on the relationship between fiscal decentralization and income inequality is concentrated in developed countries, while research within the developing country is very limited. The impact of fiscal 
decentralization on the economic growth and well-being of the people in the country is an important consideration in academic research. To date, theories have identified the potential effects of fiscal decentralization on a country, including economic growth, regional income disparity, macroeconomic stability, corruption and government size (Martinez-Vazquez al et., 2017).

Moreover, fiscal decentralization is not an objective of national policies. It is the nation's strategy of pursuing, reorganizing public sector activities, and making public sector operations more effective when responsible for the needs and interests of the people. However, the level of fiscal decentralization depends on political institutions, economic and social factors, and history; and the province's per-capita income inequality compared to the nation's per capita income can also be considered as a result achieved in the socioeconomic framework where public policy is implemented. (Sepulveda, 2010).

However, there is a situation where many countries are experiencing slowing economic growth, due to uneven growth among regions within one country and the increasing income concentration of the central government. Concerns about these issues have spurred policy discussions to ensure more inclusive and multi-dimensional economic growth. An important solution to addressing these concerns is through fiscal relations between central and local governments. Through decentralization, it will improve the rules and practices of local governments in policy-making, which can shape fiscal policy and positive multidimensional results at all levels of government. (Kim \& Dougherty, 2018). One of the factors that slow down the economic growth rate of localities, leading to income inequality between localities, is the right quality of the locality (Nicholas D'Amico, 2015). ). Another factor that is determined to change and control corruption in each locality is the level of fiscal decentralization between the locality and the central government. Each political system has different fiscal decentralization for different reasons (Ebel \& Yilmaz, 2002), for developed countries mainly decentralized to provide public services more effectively, while low-income countries pursue decentralization as a way to overcome macroeconomic instability, improve the efficiency of public administration and reduce income disparities across provinces.

In terms of research methodology, the majority of current empirical studies consider the possibility of simultaneously producing the least square estimates (OLS) of hypothesized relationships and have used tool transformation techniques such as two-stage minimum squares (2SLS) to solve this problem. A problem raised, the temporal existence of fiscal decentralization and income inequality in terms of the impact of lag variables represent exogenous tools. Although the same problem does not appear in cross-sectional data, it can be argued that some of the instruments used did not satisfy the mutually-exclusive restrictions. Furthermore, there are concerns about sample sizes, due to the limited availability of countries for key variables.

In fact, Vietnam is a developing country with many interesting issues. There is income inequality between provinces. Provinces are encouraged to attract foreign investment for economic development, but they were concerned about corruption in the locality. Export value is driven from investing capital in the host country in the process of exploiting low-cost labor, transferring technology and knowledge approach (Nguyen, 2020), preferential policies in trade liberalization agreements, as well as positive exchange rate policies of countries to trading partners (Abbas et al., 2020).

The study is based on a panel data of 63 provinces/cities under the central authority of Vietnam. This study has strong evidence of the positive impact of fiscal decentralization on local corruption control, as well as evidence that poor government quality (high corruption) will tend to be more concentrated. Moreover, strong evidence appears for the claim that the government has a high level of corruption and it will be more difficult to reduce income inequality between localities as well as the idea that countries with large inequality will tend to be less dominated. Finally, empirical findings point to expectation that a higher level of fiscal decentralization will tend to reduce regional inequality. But it is not assumed that income disparities among centers should have different levels of fiscal decentralization. The analysis also shows that previous studies examining the determinants of regional inequality and fiscal decentralization may suffer a degree of variable bias because it does not control the confounding effect of government quality.

Empirical results in Vietnam show that: (1) fiscal decentralization enhances the status of provinces through corruption control in poor areas, encouraging economic growth policies, and reducing inequality in the region. Fiscal decentralization may increase income inequality across provinces; the level of fiscal decentralization again depends on income inequality and fiscal decentralization and will improve the political capacity of local governments; (2) increasing corruption increases the inequality of per-capita income of provinces compared to the average per-capita income of the whole country, and increases the level of anticorruption; and (3) income inequality also affects the ability to control corruption and fiscal decentralization.

Almost all previous studies only approached each equation separately to examine (i) the relationship between fiscal decentralization to income inequality, (ii) the relationship between fiscal decentralization and corruption, or (iii) corruption to income inequality. There have not yet been studies examining the simultaneous relationship between fiscal decentralization, corruption, and income inequality in the context of developing countries. Therefore, we carry out research on this issue to fill the theoretical and practical knowledge. The study uses the estimation method 3SLS- 
GMM (Three Stage Least Squares - Generalized Method of Moments Estimator) and GMM-HAC (Generalized Method of Moments - Heteroskedastic and Autocorrelation Consistent Estimator) in order to systematically estimate the structural equations, in which the residuals of each equation are correlated, as well as some equations have endogenous variables (Zellner \& Theil, 1962).

The study is structured as follows: after the introduction, Section 2 examines the theory and empirical results of the complex relationship between the three variables analyzed in the study. Section 3 describes the data, while Section 4 presents the empirical model and methodology used in the analysis. Finally, Section 5 provides conclusions and policy implications.

\section{Literature Review}

With the goal of shedding light on the simultaneous relationship between fiscal decentralization, corruption control and income inequality, the research will systematize the unique relationship of previous studies.

\subsection{Fiscal Decentralization and Income Inequalities}

Fiscal decentralization may narrow or widen regional income inequalities. It can reduce inequality in the region because fiscal decentralization encompasses more specific policies and information (Oates, 1972, 1993). At the same time, the fiscal decentralization helps the local to have specific information on the needs of the people so that they can adjust and make specific policies for each locality (Oates, 1972). Moreover, fiscal decentralization can promote competition to attract local financial resources and make local public service delivery more efficient (Salmon, 1987; Breton, 1996). Thus, the fiscal decentralization will have effective policies in local economic development, reducing income inequality among regions in the long term (Oates, 1993).

As per previous empirical studies, the impact of fiscal decentralization on regional income inequality can be divided into separate groups for developed countries, or research for both developed and developing countries, or individual studies for each country. For studies in the case of national scope, fiscal decentralization was found to increase fiscal regional disparities in China (Kanbur \& Zhang, 2005; Qiao et al., 2008), Philippines (Silva, 2005) and Colombia (Bonet, 2006), while it has reduced the gap in the US (Akai \& Hosio, 2009) and Italy (Calamai, 2009). In addition, fiscal decentralization has been found as a factor to reduce income disparities in European Union countries (Ezcurra \& Pascual, 2008) and OECD countries (Gil et al., 2004; Lessmann, 2009). Thereby, there are many inconclusive findings when analyzing among countries. Specifically, fiscal decentralization has been found to increase regional disparities in poor countries, while in richer countries it is either neutral or tends to reduce disparities (RodríguezPose \& Ezcurra, 2010; Lessmann, 2012). Tariq et al. (2020) shows the non-linear relationship between the development of financial resources to Pakistan's economic growth in the period 1980-2017. The physical capital, labor resources and government expenditure are the important factors enhancing economic growth.

Currently, political, legal, and financial institutions are undergoing significant changes in many developed countries. Developed countries have recently implemented policy decentralization reforms aimed at increasing the autonomy of lower-level governments and reducing the inefficiency of central fiscal policy. Fiscal decentralization is driven by the need to use public resources more effectively, by assigning policy control and empowerment to the local level with positive additional outcomes for economic development in a countries (Bahl \& Linn, 1992; Musgrave, 1959; Oates, 1972; Stigler, 1957). Recently, Kanbur and Zhang (2005) considered the context of increasing spending decentralization in China to increase regional income inequality. Akai and Sakata (2005) argue that increased anticorruption of income sources reduces income inequality in the region, reduces the financial dependence of local governments and promotes economic growth in poor areas.

Heterogeneous incentive policies across regions can lead to support for decentralization, for the potential benefit of welfare or for increased efficiency of local management (Oates, 1997) needs through diversified activities public products suit local circumstances (Oates, 1972). Accordingly, regional economic inequalities can play an important role in specific fiscal decentralization as follows: (1) disparities in economic development in high regions can increase the desire for higher levels of autonomy and fiscal decentralization (Bolton \& Roland, 1997); (2) if some provinces and regions are too poor to provide essential public services, through the transfer of resources from provinces, rich areas to finance low-income localities across the country are decided by the central government. From there, the income gap and welfare can be improved, (Buchanan, 1950; Rodden, 2010). In this case, however, it is often more opposed than favored by affluent and prosperous localities. Result of competition between local governments through tax policies and public goods making the redistribution policy impossible (Musgrave, 1959; Oates, 1972; Stigler, 1957), whereby to ensure fair redistribution needs to be implemented at the central level.

\subsection{Income Inequality and Corruption}

Next, consider the relationship between government quality, local government's ability to control corruption, and regional income inequality. As regards the relationship of inequality to government quality, Kyriacou (2012, 2014) argues that regional income inequality can reduce the quality 
of government and reduce public confidence. To test this inverse causality, this author uses the latency values of regional inequality in regression models, cross-sectional tool variables. Kyriacou and Roca-Sagalés (2014) provide empirical evidence to suggest that income disparities in the region can lead to conflicts in the redistribution of resources, one of the remedy policies is an effort to improve the quality of public administration and control corruption. Improving government quality reduces income inequality (Andreas, 2013).

In the opposite direction, the results of the study have also been suggested that government quality can influence the positive change of regional income inequality. Ezcurra and Rodríguez-Pose (2014) argue that an effective regional development strategy and public administration capacity will attract foreign direct investment (FDI). And this ability may be negatively affected by poor governance. Their empirical evidence demonstrates the positive impact of quality government on regional convergence. In another article, Kyriacou et al. (2015) consider both the direct impact of government quality on regional inequality and the previous mediating impact on the impact of fiscal decentralization on regional inequality. They find that better governance tends to reduce regional inequality directly. Meanwhile, the mediating effect of governance indicates that financial decentralization increases regional inequality at low levels of government quality settings and reduces them in the high quality of government. To control reverse causality in regression, Kyriacou et al. (2015) noted employers delayed the value of government quality as a tool and tried to reinforce the exception of the instruments by taking the latency of some lengths. Ezcurra and Rodríguez-Pose (2014) take a different approach and the quality of government tools with the press freedom index which they show is correlated with the quality of government while, they argue, it is exogenous with regional inequality.

\subsection{Fiscal Decentralization and Corruption}

Finally, consider the relationship between fiscal decentralization and the quality of government, as well as the factors that control corruption. The quality of government has been defined as the extent to which the state protects ownership rights at the national level. It is not affected by corruption, controls corruption and provides public goods in a cost-effective manner (La Porta et al., 1999). Fiscal decentralization can improve public administration, as fiscal decentralization can promote regional convergence. Because it empowers local governments to have better policies and create competition between regions in attracting revenue. And this problem can lead to negativity if run by poor government. In addition to fiscal decentralization, it is possible to make efficient use of financial resources at each decentralized level, in the context of decentralized government (Shleifer \& Vishny, 1993). However, the decentralization is too high, leading to the situation that local officials may be controlled by economic interest groups (Prud'homme, 1995; Bardhan \& Mookherjee, 2006; Bardhan, 2002). Governments in non-transparent areas will be the engines to weaken laws and develop business-friendly policies (Rodden \& RoseAckerman, 1997; Cai \& Treisman, 2004, 2005). This suggests that previous theories have been given arguments to explain why fiscal decentralization can reduce or increase government quality.

Using cross-country data, Fisman and Gatti (2002) find that, in countries with decentralized fiscal mechanisms, there is a tendency to be less corrupt. This result has been recognized by scholars based on evidence of cross data and table data (Enikolopov \& Zhuravskaya, 2007; Fan et al., 2009; Kyriacou \& RocaSagalés, 2011a, 2011b). They also confirm that officials in countries with poor governance can counter fiscal decentralization, maintain centralization in the management and use of public resources.

\section{Data Description}

The research data is collected by year in the period 20112018 , including data of the whole country and 63 provinces/ cities under central authority in Vietnam, sourced from the General Statistics Office and the Ministry of Finance of Vietnam. Except for the data on the Provincial Corruption Control Index (Papic) from the PAPI dataset of the Center for Development Studies - Community Support (CECODES) of the Vietnam Union of Science and Technology Associations and the United Nations Development Program (UNDP) in Vietnam, the remaining data sources were collected from the General Statistics Office (provincial data) and the World Bank (national data). Therefore, the data ensures homogeneity and reliability to perform the verification. The data sources used for this study are summarized in Table A1 of the Appendix. From the internal data source, the study obtained descriptive statistical results for the variables in the model summarized in Table A2 of the attached appendix.

Table A1 shows that the collected table data is perfectly balanced with the maximum number of observations of 504 observations for 63 provinces/cities during the 8-year survey period from 2011 to 2018. With a maximum score of 100 for the case where the locality is perfectly competitive, in the period 2011-2018, in general, Provinces across the country have corruption control indexes, with the lowest score 36.39 and the highest 77.19.

\section{Models and Estimation Methods}

\subsection{Research Model}

From the theoretical basis and the results of previous empirical research, we show the existence of a simultaneous cause and effect relationship between fiscal decentralization, income inequality and corruption in the following model: 


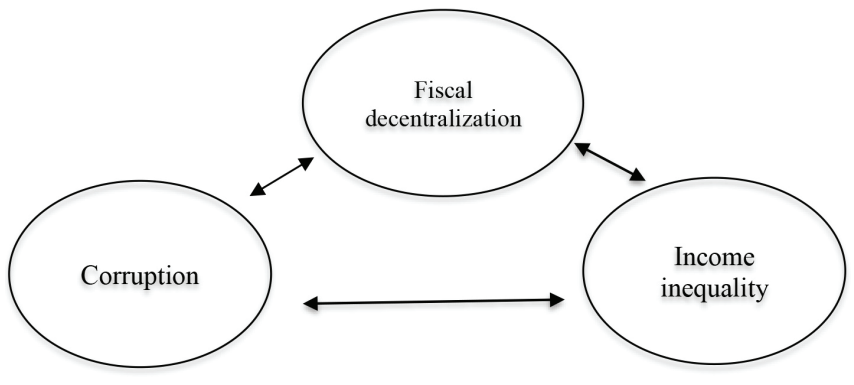

Figure 1: Complex relationship between fiscal decentralization, Corruption and Income inequality

To fulfill research objectives, on the concurrent relationship between corruption-fiscal decentralizationincome inequality in provinces/cities across the country. At the same time, based on the interdependence and interaction between main variables, the simultaneous equation model (SEM Simultaneous Equation Model) consists of three equations, with the following general form:

$$
\begin{aligned}
& R I_{i t}=\mu_{0}+\mu_{1} F D_{i t}+\mu_{2} \operatorname{CORRUPT}_{i t}+\mu_{3} X_{1, i t}+u_{1, i t} \\
& F D_{i t}=\eta_{0}+\eta_{1} R I_{i t}+\eta_{2} \operatorname{CORRUPT}_{i t}+\eta_{3} X_{2, i t}+u_{2, i t} \\
& \text { Corrupt }_{i t}=\lambda_{0}+\lambda_{1} R I_{i t}+\lambda_{2} F D_{i t}+\lambda_{3} X_{3, i t}+u_{3, i t}
\end{aligned}
$$

Inside:

- The subscript $\mathrm{i}$ represents provinces / cities, $\mathrm{t}$ is the time.

- CORRUPT is a Papic index. Corruption control variable for each province in the data set (PAPI). This indicator is expressed by the people's perception of their ability to control corruption in the public sector (PAPIC). Accordingly, the higher the index of corruption control, the more the people appreciate the quality of government.

- FD is the proxy for fiscal decentralization of province $i$ at time t. Specifically, the decentralized autonomy revenue of the province (RD1) is calculated by the revenue from the $100 \%$ provincial tax and other nontax revenue per capita of the province compared to the total national revenue per capita of the whole country built by Gemmell (2013) and Stegarescu (2005).

- RI is the province's income inequality, represented by the index, PW_CV is the variable representing the difference in income per capita of province i compared to the national per capita income at time t (Cowell, 1995; See also Williamson, 1965; Ezcurra \& Pascual, 2008; Lessmann, 2009; Rodríguez-Pose \& Ezcurra, 2010).

- $\mathrm{X} 1$ is a set of control variables included in the inequality equation based on economic growth theories such as per capita income, trade openness, investment expenditure, high school graduation rate and the government's 135 support program (Program 135 is a program of socio-economic development in extremely difficult communes in ethnic minority and mountainous areas, is one of the poverty reduction programs in Vietnam that has been implemented by the Government of Vietnam since 1998)

- X2 is a set of control variables in the fiscal decentralization equation, including variables such as per capita income, trade openness.

- X3 is a set of control variables in the corruption equation, including income per capita, trade openness.

- $\mathrm{u} 1, \mathrm{u} 2, \mathrm{u} 3$ are error components of equations in the SEM system. These errors include specific factors of each province (do not change over time).

Note: The study uses logarithmic income per capita variable (lgdp) to eliminate the impact of the influence points as well as maintain the multivariate standard distribution in the model.

\subsection{Method of Estimation}

With the potential for mutual interactions between the main variables in the model, an estimation method that can be considered for mutual interaction can be applied to avoid biases in the analysis. Here, the reciprocal interaction can be the correlation of the residuals between the equations, as well as the correlation between the main variables acting as explanatory variables in the remaining equations and the error of that equation (endogenous variables). In addition, in cases where the residual variance of equations is heterogeneous across provinces or in other words the system exists variance change, this issue should be considered in SEM. In the SEM system these problems can be accomplished by estimating GMM in two ways. These are 3-step regression estimates (3SLS-GMM) and GMMHAC estimates to overcome the problem of simultaneous variance and correlation of residuals in the system (Andreas et al., 2015).

Compared to the individual approach to each equation, the system estimation approach can take into account the reciprocal effects between the main variables, and achieve more reliable and efficient estimation results (Andreas et al., 2015). Depending on the specific characteristics of the mutual impacts, an appropriate estimation method can be selected among the estimates such as 2-step regression (2SLS), almost unrelated estimation (SUR) or 3SLS-GMM estimates. In particular, the estimation of 3SLS-GMM is a combination of 2-step regression method and SUR regression method. The 3SLS-GMM method is used to estimate the system of structural equations. In which the remainder of each equation is self-correlated, as well as some equations exist endogenous variables (Zellner \& Theil, 1962). In our study, the 3SLS method was used to estimate the relationship between fiscal decentralization, corruption and income inequality across 
provinces through the "reg3" command on software Stata 14 version 2. In Stata, "reg3" command is used to estimate a system of structural equations with setting each equation contains endogenous explanatory variables are dependent variables from other equations in the system. Estimation is via three-stage least squares (3SLS). A dependent variable will have its usual interpretation as the left-hand-side variable in an equation with an associated disturbance term. All dependent variables are explicitly taken to be endogenous to the system and are treated as correlated with the disturbances in the system's equations (Davidson \& MacKinnon, 1993; Greene, 2012).

Besides, in addition to the endogenous variables in the model, the explanatory variables of each equation are considered strictly exogenous variables in the model and is used as a instruments for the endogenous variables in the corresponding equation. Specifically, it is the RI variable in the equations of FD and CORRUPT, or FD in the RI and CORRUPT equations, as well as the CORRUPT variable will be endogenous in the RI and FD equations. Correlation of noise errors with these endogenous variables violates the OLS assumption. Moreover, because some explanatory variables are dependent variables of other equations in the system, the noise errors between the equations can be correlated. The 3SLS-GMM method uses a tool variable approach to generate reliable estimates and the GLS approach in SUR estimates to consider the correlation of residuals (Davidson \& MacKinnon, 1993, pp. 651-661; Greene, 2012, pp. 331334). As such, the study will use the 3SLS-GMM method in combination with the GMM-HAC estimation to control HAC to estimate the concurrent relationship between income inequality - fiscal decentralization and control of corruption. The estimation process of GMM-3SLS is done through three steps as follows:

Step 1: Create a representative value for all endogenous variables. Put simply, these representative values can be considered as predicted values from the regression results of each endogenous variable according to all exogenous variables in the system (reduced form equation). This phase is similar to the first stage in the 2SLS method and is necessary to ensure confidence in the estimation of parameters.

Step 2: Develop a reliable estimate for the covariance matrix of the noise errors of equations. The value of these estimates is taken from the residuals of the 2SLS estimates for each structural equation in the system.

Step 3: Perform GLS estimates using the covariance matrix generated in step 2, along with using surrogate values for endogenous variables on the right.

The results of each estimate will be tested for the appropriateness of the model by over-constraining test through J-Hansen statistics on the suitability of the tool variables. Buam (2006, p. 201) states that J-Hansen statistical test is the most popular test in GMM estimation to check the suitability of the model. The J-Hansen statistical test is used to test the H0 hypothesis about whether the model is correctly identified and to check for excessive constraints or the rationality of representative variables. Rejection of the $\mathrm{H} 0$ hypothesis means that one of the two assumptions about the appropriateness of the model or representative variable is questionable.

\section{Results, Conclusions and Implications}

\subsection{Research Results}

The estimation results of the 3SLS-GMM and GMMHAC methods in the case of the variable representing the fiscal decentralization FD are the local autonomy revenue sources, shown in Table 2. The results show that, there exists a two-way relationship between fiscal decentralization, income inequality, and corruption. Accordingly, in the absence of other factors, fiscal decentralization has a positive effect on income inequality and corruption. Increasing fiscal decentralization will increase corruption control, as well as increase regional income inequality. Conversely, improving provincial-level corruption control will reduce income inequality among provinces, while increasing fiscal decentralization. Similarly, an increase in the per capita income inequality between provinces will increase fiscal decentralization and reduce corruption control during the survey period.

The appropriateness of each estimation method will be checked through J-Hansen statistics. With $\mathrm{p}$ value greater than 0.05 , the test results in both 3SLS-GMM and GMM-HAC methods both accept the H0 hypothesis. That means that the tool variables used in the model are appropriate. In addition, the results also suggest that increasing per capita income will increase regional inequality, reduce fiscal decentralization and improve the quality of government of each province. The same is true for trade liberalization.

\subsection{Conclusions}

Systematic research included reassessing theories related to the determinants of regional income inequality, fiscal decentralization and government quality, concluding that these three variables interact with each other simultaneously. In comparison with previous empirical studies, we have tried to cope with the possibility of feedback effects between variables, and implemented through estimating tool variables based on tools that are questionable for validity. In this paper, our study is based on the SEM estimation method, successfully dealing with the interdependence between variables. With the panel data collected from 63 provinces and cities of Vietnam between 2011 and 2018, we have made estimates derived from the proposed model, our findings are interesting. 
Hung Thanh NGUYEN, Thuy Hoang Ngoc VO, Duc Doan Minh LE, Vu Thanh NGUYEN /

Journal of Asian Finance, Economics and Business Vol 7 No 11 (2020) 529-540

Table 2: Results of estimating the simultaneous relationship between RI - FD - CORRUPT

\begin{tabular}{|l|c|c|c|c|c|c|}
\hline \multirow{2}{*}{} & \multicolumn{3}{|c|}{ 3SLS-GMM } & \multicolumn{3}{c|}{ GMM-HAC } \\
\cline { 2 - 7 } & $\begin{array}{c}\text { Equation } \\
\text { (1) RI }\end{array}$ & $\begin{array}{c}\text { Equation } \\
\text { (2) FD }\end{array}$ & $\begin{array}{c}\text { Equation } \\
\text { (3) Corrupt }\end{array}$ & $\begin{array}{c}\text { Equation } \\
\text { (1) RI }\end{array}$ & $\begin{array}{c}\text { Equation } \\
\text { (2) FD }\end{array}$ & $\begin{array}{c}\text { Equation } \\
\text { (3) Corrupt }\end{array}$ \\
\hline RI & & $4.573^{* * *}$ & $-1.009^{* * *}$ & & $4.078^{* * *}$ & $-0.350^{* * *}$ \\
\hline FD & $0.219^{* * *}$ & & $0.220^{* * *}$ & $0.201^{* * *}$ & & $0.076^{* * *}$ \\
\hline Log of GDP & $-0.987^{* * *}$ & $4.500^{* * *}$ & & $-0.598^{* * *}$ & $2.162^{* * *}$ & \\
\hline Openness & 0.017 & -0.08 & 0.018 & $0.019^{* * *}$ & -0.008 & $0.037^{* * *}$ \\
\hline Public investment & $0.011^{* *}$ & $-0.049^{* *}$ & $0.011^{* *}$ & $0.004^{*}$ & -0.016 & $0.005^{*}$ \\
\hline Dummy for Benefits & -0.0007 & & & $0.088^{* * *}$ & & \\
\hline High School Graduation Rate & -0.00003 & & & $-0.003^{* *}$ & & \\
\hline -cons & 0.0015 & & & -0.094 & & \\
\hline J-test & $0.511^{* * *}$ & $-2.329^{* * *}$ & $0.517^{* * *}$ & $0.297^{* * *}$ & $-1.211^{* * *}$ & $0.461^{* * *}$ \\
\hline
\end{tabular}

Note: Symbols: $\left({ }^{*}\right),\left({ }^{* *}\right),\left({ }^{* * *}\right)$ correspond to the statistical significance level of $1 \%, 5 \%$ and $10 \%$.

First, there exists a two-way relationship between corruption, fiscal decentralization, and regional income disparity at $1 \%$ significance level.

Secondly, the higher the local revenue autonomy, the higher the province's ability to control corruption. At the same time, the higher the ability to control local corruption, also makes this revenue decentralization higher. This implies that the more corrupt the provinces are, the less the impact of $100 \%$ tax revenue and local non-tax revenues.

Thirdly, controlling corruption has an opposite effect to income inequality; this thesis reflects the provinces with corruption and high governance efficiency, narrowing the gap between the province's per capita income and the country's average per capita income.

Fourthly, fiscal decentralization has a positive impact on income inequality, $100 \%$ local revenue from local taxes and other non-tax revenues compared to the total revenue of the country as a proportion. The more the population increases, the higher the income disparity of that locality. However, the income inequality also has a positive impact on the decentralization of autonomy income sources of the provinces.

\subsection{Policy Implications}

In view of the current situation in Vietnam, the research results point to policy implications to improve corruption control of provinces. In order to reduce the difference between the average per-capita income of the provinces and the national average per-capita income, the following issues should be considered:
Firstly, promoting fiscal decentralization to improve provincial corruption control, improve the governance efficiency of local governments at all levels, improve the control of corruption across provinces, through the development of financial resources, select and participate in free trade policies, and introduce export encouragement policies to increase local autonomy revenue. Since then improving the ability to control corruption and governance efficiency, indirectly reduce income inequality between provinces.

Second, an increase in the share of public spending from the central government, namely, as expenditures for recurrent activities (education and health care). For extremely difficult areas, it is necessary to promote project spending activities like the current 135 program. In summary, the study provides reliable evidence for Vietnamese policymakers. In particular, the study suggests that the goal is to narrow income inequality across provinces. It is a fiscal decentralization process with measures to improve the quality of government (fighting against corruption and improving bureaucracy efficiency) will be an effective strategy, at least in this sample. The results also show that it is difficult for policy makers to apply appropriate policies on fiscal structure. On the other hand, the presence of regional inequality may undermine efforts to improve the efficiency of the public sector and on the other hand, corrupt, ineffective governments can counter fiscal decentralization. This does not mean that countries with large regional inequalities and lower government quality cannot be improved through appropriate policies. Instead, the desired policy change may face restrictions or additional restrictions. 
Third, the empirical findings from data from a developing country like Vietnam should imply that the policy is only relevant to developing countries. This is the limitation of the study, a problem for future research, if there is sufficient data to explore the relationship between the three variables studied in this article in a broader sample for both developed and developing countries, more comprehensive research results underpin broader implications. For example, developing countries tend to have greater regional inequality (Lessmann, 2012), fiscal decentralization is more concentrated (World Bank, 1999, 2000) and has lower government quality. (La Porta et al., 1999).

In summary, the 3SLS-GMM (Three Stage Least Squares - Generalized Method of Moments Estimator) and GMMHAC (Generalized Method of Moments - Heteroskedastic and Autocorrelation Consistent estimator) have overcome the autocorrelation, as well as some equations have endogenous variables (Zellner \& Theil, 1962) compared with the separate approach to each equation. Since then, the study shows strong evidence of the existence of a simultaneous relationship between fiscal decentralization, corruption, and income inequality within a country. However, this problem is consistent with the theoretical argument and empirical evidence provided in this article. The proposal for further research is to expand the sample to include developed and developing countries to gain a new understanding of the complex relationship between income inequality, fiscal decentralization, and the quality of government in a variety of contexts.

\section{References}

Ades, A. \& Di Tella, R. (1999). Rents, competition and corruption, American Economic Review, 89(4), 982-993.

Alesina, A., \& Spolaore, E. (2003). The size of nations. Cambridge MA: MIT Press.

Arzaghi, M., \& Henderson, V. (2005). Why countries are fiscally decentralizing. Journal of Public Economics, 89, 1157-1189.

Avery, R. (1977). Error components and seemingly unrelated regressions. Econometrica, 45, 199-209.

Alesina, A., \& Zhuravskaya, E. (2011). Segregation and the quality of government in a cross-section of countries. American Economic Review, 101(5), 1872-1911.

Acemoglu, D., Johnson, S., \& Robinson, J. (2001). The Colonial Origins of Comparative Development: An Empirical Investigation. American Economic Review, 91, 1369-1401.

Andrews, D. W. K. (1991). Heteroskedasticity and autocorrelation consistent covariance matrix estimation. Econometrica, 59, $817-858$

Baum, C. F. (2006). An Introduction to Modern Econometrics Using Stata. College Station, TX: Stata Press.

Baltagi, B. H. (1981). Simultaneous equations with error components. Journal of Econometrics, 17, 189-200.
Baltagi, B. H. (2008). Econometric Analysis of Panel Data (4 ${ }^{\text {th }}$ ed.). Chichester, UK: Wiley and Sons.

Bardhan, P. (2002). Decentralization of government and development. Journal of Economic Perspectives, 16(4), 185-205.

Bardhan, P., \& Mookherjee, D. (2006). Decentralization, corruption and government accountability: an overview. In: S. RoseAckerman (Ed.), International Handbook on the Economics of Corruption (pp. 161-188). Cheltenham, UK: Edward Elgar.

Barro, R. (2000). Inequality and growth in a panel of countries. Journal of Economic Growth, 5(1), 5-32.

Barro, R. (2001). Human capital and growth. American Economic Review, 91(2), 12-17.

Barro, R., \& Lee, J. (2001). International data on educational attainment: Updates and implications. Oxford Economic Papers, 53(3), 541-563.

Bazzi, S., \& Clemens, M. (2013). Blunt instruments: avoiding common pitfalls in identifying the causes of economic growth. American Economic Journal: Macroeconomics, 5(2), 152- 186.

Beramendi, P. (2007). Inequality and the Territorial Fragmentation of Solidarity. International Organization, 61, 783-820.

Bjorn, E., \& Krishnakumar, J. (2008). Measurement errors and simultaneity. In: L. Mátyás, \& P. Sevestre (Eds.), The Econometrics of Panel Data. Fundamentals and Recent Developments in Theory and Practice (Chapter 10, pp. 323-367).

Brennan, G., \& Buchanan, J. (1980). The power to tax. Analytical foundations of a fiscal constitution. Cambridge, UK: Cambridge University Press.

Cai, H., \& Treisman, D. (2004). State corroding federalism. Journal of Public Economics, 88, 819-843

Cai, H., \& Treisman, D. (2005). Does competition for capital discipline government? Decentralization, globalization and public policy. American Economic Review, 95(3), 817-830

Cameron, A. C., \& Trivedi, P. K. (2005). Microeconometrics: Methods and Applications. Cambridge, UK: Cambridge University Press.

Costa-Font, J. (2010). Does devolution lead to regional inequalities in welfare activity? Environment and Planning C: Government and Policy, 28(3), 435-449.

Davidson, R., \& MacKinnon, J. G. (2004). Econometric Theory and Methods. New York, NY: Oxford University Press.

Elazar, D. (1995). From statism to federalism: a paradigm shift.' Publius. The Journal of Federalism, 25, 5-18.

Enikolopov, R., \& Zhuravskaya, E. (2007). Decentralization and Political Institutions. Journal of Public Economics, 91(11-12), 2261-2290.

Ezcurra, R. (2012). Is there a link between globalization and governance? Environment and Planning C. Government and Policy, 30(5), 848-870.

Ezcurra, R., \& Pascual, P. (2008). Fiscal decentralization and regional disparities: Evidence from several European Union countries. Environment and Planning A, 40, 1185-120. 
Ezcurra, R., \& Rodríguez-Pose, A. (2014). Government quality and spatial inequality: A cross- country analysis, Environment and Planning A, 46(7), 1732-1753.

Gil, C., Pascual, P., \& Rapun, M. (2004). Regional economic disparities and decentralization. Urban Studies, 41(1), 71-94.

Glaeser, E., Scheinkman, J., \& Shleifer, A. (2003). The injustice of Inequality. Journal of Monetary Economics, 50, 199-222.

Fan, S., Lin, C., \& Treisman, D. (2009). Political decentralization and corruption: evidence from around the world. Journal of Public Economics, 93, 14-34.

Fisman, R., \& Gatti, R. (2002). Decentralization and corruption: Evidence across countries. Journal of Public Economics, 83, 325-345.

Gemmell, N., Kneller, R., \& Sanz, I. (2013). Fiscal decentralization and economic growth: Spending versus revenue decentralization. Economic Inquiry, 51(4), 1915-1931.

Giannetti, M. (2002). The effects of integration on regional disparities: Convergence, divergence or both? European Economic Review, 46(3), 539-67

Gil, C., Pascual, P., \& Rapun, M. (2004). Regional economic disparities and decentralization. Urban Studies, 41(1), 71-94 26

Greene, W. H. (2012). Econometric Analysis (7th ed.). Upper Saddle River, NJ: Prentice Hall.

Hall, R., \& Jones, C. (1999). Why do some countries produce so much more output per worker than others? Quarterly Journal of Economics, 114(1), 83-116.

Hayashi, F. (2000). Econometrics. Princeton, NJ: Princeton University Press.

Jin, H., Yingyi, Q., \& Weingast, B. (2005). Regional decentralization and fiscal incentives: Federalism Chinese style. Journal of Public Economics, 89(9-10), 1719-1742.

Kuznets, S. (1955). Economic growth and income inequality. The American Economic Review., XLV. https://assets.aeaweb.org/ asset-server/files/9438.pdf

Kyriacou, A. (2012). Ethnic segregation and the quality of government: the importance of regional diversity. Constitutional Political Economy, 23(2), 166-180.

Kyriacou, A., \& Roca-Sagalés, O. (2011a). Fiscal and political decentralization and government quality. Environment and Planning C (Government and Policy), 29(2), 204-223.

Kyriacou, A., \& Roca-Sagalés, O. (2011b). Fiscal decentralization and government quality in the OECD. Economics Letters, 111(3), 191-193.

Kyriacou, A., \& Roca-Sagalés, O. (2012). The impact of EU structural funds on regional disparities within member states. Environment and Planning C (Government and Policy), 30(2), 267-281.

Kyriacou, A., \& Roca-Sagalés, O. (2014). Regional disparities and government quality: Redistributive conflict crowds out good government. Spatial Economic Analysis, 9(2), 183-201.
Kyriacou, A., Muinelo-Gallo, L., \& Roca-Sagalés, O. (2014). Fiscal decentralization and regional disparities: The importance of good governance. Forthcoming, Papers in Regional Science, DOI: $10.1111 /$ pirs.12061

Keen, M., \& Marchand, M. (1997). Fiscal competition and the pattern of public spending. Journal of Public Economics, 66, 33-53.

Kmenta, J. (1997). Elements of Econometrics. Second Edition Annual Arbor: University of Michigan Press.

La Porta, R., Lopez-de-Silanes, F., Shleifer, A., \& Vishny, R. (1999). The quality of government. Journal of Law, Economics and Organization, 15(1), 222-279.

Lessmann, C. (2009). Fiscal decentralization and regional disparity: Evidence from cross section and panel data. Environment and Planning A, 41, 2455-2473.

Lessmann, C. (2012). Regional inequality and decentralization: an empirical analysis. Environment and Plannning A, 44, 1363-1388.

Letelier, L. (2005). Explaining fiscal decentralization. Public Finance Review, 33, 155-183.

Lin, S., Kim, D., Huang, H., \& Yeh, C. (2009). Nonlinearity between inequality and growth. Studies in Nonlinear Dynamics Econometrics, 13(2). DOI: 10.2202/1558-3708.1635

Mankiw, G., Romer, D., \& Wei, 1. D. (1992). A contribution to the empirics of economic growth. Quarterly Journal of Economics, 107(2), 407-437.

Matyas, L. (1999). Generalized Method of Moments Estimation. Cambridge, UK: Cambridge University Press.

Mauro, P. (1995). Corruption and Growth. Quarterly Journal of Economics, 110(3), 691-712.

McKinnon, R. (1997). Market-preserving fiscal federalism in the American monetary union. In: M. Blejer, \& T. Ter-Minassian (Eds.), Macroeconomic dimensions of public finance: Essays in honour of Vito Tanzi (pp. 73-93). London, UK: Routledge.

Newey, W. K., \& West, K. D. (1987). A simple, positive semidefinite heteroskedasticity and autocorrelation consistent covariance matrix. Econometrica, 56, 203-208.

Newey, W. K., \& West, K. D. (1994). Automatic lag selection in covariance matrix estimation. Review of Economic Studies, 61, 631-653.

Nguyen, V. C., \& Do, T. T. (2020). Impact of Exchange Rate Shocks, Inward FDI and Import on Export Performance: A Cointegration Analysis. Journal of Asian Finance, Economics and Business, 7(4), 163-171. https://doi.org/10.13106/ jafeb.2020.vol7.no4.163

Oates, W. (1993). Fiscal decentralization and economic development. National Tax Journal, 46(2), 237-243.

Oates, W. (1999). An essay on fiscal federalism. Journal Economic Literature, 37, 1120-1149.

Panizza, U. (1999). On the determinants of fiscal centralization: Theory and evidence. Journal of Public Economics, 74, 97-139. 
Petrakos, G. (2001). Patterns of regional inequality in transition economies. European Planning Studies, 9, 359-383.

Petrakos, G., Rodríguez-Pose, A., \& Rovolis, A. (2005). Growth, integration and regional disparities in the European Union. Environment and Planning A, 37, 1837-1855.

Prud'homme, R. (1995). On the dangers of decentralization. World Bank Research Observer, 10(2), 201-220.

Qian, Y., \& Roland G. (1998). Federalism and the soft budget constraint. American Economic Review, 88(5), 1143-1162.

Qian, Y., \& Weingast, B. (1997). Federalism as a commitment to preserving market incentives. Journal of Economic Perspectives, 11, 83-92.

Rodden, J. (2004). Comparative federalism and decentralization. On meaning and measurement. Comparative Politics, 36(4), 481-500.

Rodden, J., \& Rose-Ackerman, S. (1997). Does federalism preserve markets? University of Virginia Law Review, 83(7), 1521-1572.

Rodríguez-Pose, A. (2012). Trade and regional inequality. Economic Geography, 88(2), 109-136.

Rodríguez-Pose, A., \& Ezcurra, R. (2010). Does decentralization matter for regional disparities? A cross-country analysis. Journal of Economic Geography, 10, 619-644.

Rodríguez-Pose, A., \& Gill, N. (2004). Is there a global link between regional disparities and devolution? Environment and Planning A, 36(12), 2097-2117.

Saachi, A., \& Salotti, S. (2014a). How regional inequality affects fiscal decentralisation: accounting for the autonomy of subcentral governments. Environment and Planning $C$ (Government and Policy), 32(1), 144-162.

Shah ABBAS, Van Chien NGUYEN, Zhu YANFU, Huu Tinh NGUYEN. The Impact of China Exchange Rate Policy on its Trading Partners: Evidence Based on the GVAR Model Journal of Asian Finance, Economics and Business, 7(8), 131-141.

Seldayo, H., Elhorst, J., \& De Haan, J., (2010). Geography and governance: does space matter? Papers in Regional Science, 89(3), 625-641.

Shleifer, A, \& Vishny, R. (1993). Corruption . Quarterly Journal of Economics, 108, 599-616.

Solt, F. (2009). Standardizing the World Income Inequality Database. Social Science Quarterly, 90(2), 231-242.

Stegarescu, D. (2009). The effects of economic and political integration on fiscal decentralization: evidence from OECD countries, Canadian Journal of Economics, 42(2), 694-718.

Tanzi, V. (1998). Corruption around the world - causes, consequences, scope, and cures. IMF Staff Papers, 45, 559-594.

Tanzi, V. (2000). On fiscal federalism: issues to worry about. In: The World Bank Conference on Fiscal Decentralisation, Washington, DC.
Tariq, R., Khan, M. A., \& Rahman, A. (2020). How Does Financial Development Impact Economic Growth in Pakistan? New Evidence from Threshold Model. Journal of Asian Finance, Economics and Business, 7(8), 161-173. https://doi. org/10.13106/jafeb.2020.vol7.no8.161

Theil, H. (1971). Principles of Econometrics. London, UK: Wiley.

Treisman, D. (2000). The causes of corruption: A cross-national study. Journal of Public Economics, 76, 399-457.

Van Rijckeghem, C., \& Weder, B. (2001). Bureaucratic corruption and the rate of temptation: do wages in the civil service affect corruption, and by how much? Journal of Development Economics, 65(2), 307-331.

Voitchovsky, S. (2005). Does the profile of income inequality matter for economic growth? Distinguishing between the effects of inequality in different parts of the income distribution. Journal of Economic Growth, 10, 273290.

Wallis, J. J., \& Oates, W. E. (1988). Decentralization in the public sector: an empirical study of state and local government. In W. E. Oates (Ed.), Studies in Fiscal Federalism, Aldershot, UK: Edward Elgar.

Weingast, B. (1995). The economic role of political institutions: Market-preserving federalism and economic development. Journal of Law, Economics, and Organization, 11, 1-31.

Wheare, K. C. (1964). Federal Government. Oxford, UK: Oxford University Press.

Williamson, J. (1965). Regional inequality and the process of national development: A description of patterns. Economic Development and Cultural Change, 13, 3-45.

Wooldridge, J. M. (2010). Econometric Analysis of Cross Section and Panel Data (2nd ed.). Cambridge, MA: MIT Press.

Zellner, A. (1962). An efficient method of estimating seeming unrelated regressions and tests for aggregation bias. Journal of the American Statistical Association, 57, 348-368.

Zellner, A. (1963). Estimators for seemingly unrelated regression equations: Some exact finite sample results. Journal of the American Statistical Association, 58, 977-992.

Zellner, A., \& Huang, D. (1962). Further properties of efficient estimators for seemingly unrelated regression equations. International Economic Review, 3, 300-313.

Zellner, A., \& Theil, H. (1962). Three-stage least squares: simultaneous estimation of simultaneous equations. Econometrica, 30(1), 54-78.

Zhuravskaya, E. (2000). Incentives to provide local public goods: Fiscal federalism, Russian style. Journal of Public Economics, 76(3), 337-368. 


\section{Appendix}

Table A1: Data source used to calculate the variables in the model

\begin{tabular}{|c|c|c|}
\hline Targets & Unit & Source \\
\hline Corruption control index - Papic & Score indicator & $\mathrm{VCCl}$ \\
\hline GDP (Current price) & Billions dong & GSO \\
\hline Average population of the year & Thousand people & GSO \\
\hline Expenditure on development investment from local budget & Billions dong & GSO \\
\hline Recurrent expenditure from local budget & Billions dong & GSO \\
\hline Investment capital of FDI sector (at current prices) & Billions dong & GSO \\
\hline Exports & Thousand USD & GSO \\
\hline Import turnover & Thousand USD & GSO \\
\hline Support receipts from the Central & Billions dong & GSO \\
\hline Total state budget expenditure in the area & Billions dong & GSO \\
\hline $\begin{array}{l}\text { Some state budget revenues and expenditures nationwide and } 63 \\
\text { provinces }\end{array}$ & Billions dong & GSO \\
\hline Consumer price index $($ Previous year $=100 \%)$ & $\%$ & GSO \\
\hline Officially announced rates & VND / USD & WDI, WB \\
\hline Vietnam's GDP (current price) & VND & WDI, WB \\
\hline Consumer price index of Vietnam & $\%$ & WDI, WB \\
\hline
\end{tabular}

Note: GSO: Statistical Yearbook 2011-2018 for 63 provinces / cities - Department of Statistics 63 provinces / cities. WDI, WB: World Bank World Development Index, available at: wdi.worldbank.org/tables. VCCl: Vietnam Chamber of Commerce and Industry, visit at: http://papi. org.vn. 
Table A2: Statistical data of variables in the research model

\begin{tabular}{|c|c|c|c|c|c|c|}
\hline Variable & Definition and descriptive statistics of variables & Obs & Mean & $\begin{array}{l}\text { Std. } \\
\text { Dev. }\end{array}$ & Min & Max \\
\hline PW_CV & $P W-C V=\frac{1}{y}\left[\sum_{i=1}^{n} p_{i}\left(\bar{y}-y_{i}\right)^{2}\right]^{1 / 2}$ & 504 & .059 & .117 & .001 & 1.084 \\
\hline RD1 & $\underset{D 1}{R}=\frac{\text { Own Tax Revenue }+ \text { Nontax and Capital revenue }}{\text { Consolidated general government revenue }}$ & 504 & .237 & .731 & .001 & 10.930 \\
\hline $\begin{array}{l}\text { Corrupt } \\
\text { (PAPIC) }\end{array}$ & $\begin{array}{l}\text { Provincial public sector corruption control variables in } \\
\text { the dataset (PAPI) }\end{array}$ & 504 & 56.848 & 6.357 & 36.390 & 77.197 \\
\hline gdp & $\begin{array}{l}\text { Gross provincial nominal product (GPP) per capita } \\
\text { adjusted by provincial inflation (VND Million), from } \\
\text { GSO of Vietnam }\end{array}$ & 504 & 27.010 & 36.790 & 3.380 & 435.010 \\
\hline Openness & $\begin{array}{l}\text { Percentage of exports plus imports divided by Real } \\
\text { GDP }\end{array}$ & 504 & .767 & 1.132 & 0 & 8.941 \\
\hline $\begin{array}{l}\text { Public } \\
\text { investment }\end{array}$ & $\begin{array}{l}\text { Public investment of general government as a share of } \\
\text { GDP }\end{array}$ & 504 & .074 & .058 & .008 & .351 \\
\hline $\begin{array}{l}\text { Current public } \\
\text { spending }\end{array}$ & $\begin{array}{l}\text { Current expense of general government (on goods and } \\
\text { services and current transfers) as a share of GDP }\end{array}$ & 504 & .151 & .110 & .011 & .699 \\
\hline $\begin{array}{l}\text { Human } \\
\text { capital }(\mathrm{H})\end{array}$ & $\begin{array}{l}\text { Provincial students enrolled in colleges and universities } \\
\text { to provincial population (\%) as a proxy of human } \\
\text { capital, from GSO of Vietnam }\end{array}$ & 504 & 1.388 & 2.249 & 0.017 & 12.239 \\
\hline $\begin{array}{l}\text { Provincial } \\
\text { foreign direct } \\
\text { investment } \\
\text { (FDI) }\end{array}$ & $\begin{array}{l}\text { Provincial foreign direct investment per capita adjusted } \\
\text { by provincial inflation, from GSO of Vietnam }\end{array}$ & 504 & .049 & .105 & 0 & 1.593 \\
\hline $\begin{array}{l}\text { Rate of } \\
\text { people in } \\
\text { working age }\end{array}$ & $\begin{array}{l}\text { Average years of schooling of the population aged } 25 \\
\text { and over. }\end{array}$ & 504 & .557 & .050 & .366 & .681 \\
\hline $\begin{array}{l}\text { High School } \\
\text { Graduation } \\
\text { Rate }\end{array}$ & The province's annual high school graduation rate. & 504 & .032 & .008 & .012 & .057 \\
\hline $\begin{array}{l}\text { Dummy for } \\
\text { Benefits }\end{array}$ & $\begin{array}{l}\text { The dummy variable to evaluate provinces that receive } \\
135 \text { benefits is } 1 \text {, not } 0 \text {. }\end{array}$ & 504 & .769 & .421 & 0 & 1 \\
\hline
\end{tabular}

